\title{
Restoration after the Sumatra Earthquake Tsunami in Banda Aceh: Based on the Results of Interdisciplinary Researches by Nagoya University
}

\author{
Makoto TAKAHASHI ${ }^{1}$, Shigeyoshi TANAKA ${ }^{1}$, Reo KIMURA ${ }^{1}$, Masatomo UMitsu ${ }^{1}$, \\ Rokuro TABUCHI ${ }^{2}$, Tatsuaki KURODA ${ }^{1}$, Masataka ANDO $^{3}$ and Fumiaki KIMATA ${ }^{1}$ \\ ${ }^{1}$ Graduate School of Environmental Studies, Nagoya University, Japan \\ ${ }^{2}$ Faculty of Human Sciences, Sophia University, Japan \\ ${ }^{3}$ Institute of Earth Sciences, Academia Sinica, Taiwan
}

(Received for 31 May., 2007 and in revised from 6 Feb, 2008)

\begin{abstract}
This paper is based on the results of research by the Sumatra Earthquake Interdisciplinary or Integrated Research Team, Graduate School of Environmental Studies, Nagoya University. This research shows: (1) the Sumatra Earthquake tsunami disaster damage in Banda Aceh can be divided into four areas; (2) the tsunami action was directed left and right by the Banda Aceh topography; (3) within which District I saw total destruction of housing, a high death rate, and the collapse of families; (4) with the high death rate due to a lack of earthquaketsunami association; (5) that even in the core of housing reconstruction, the pace is slow; (6) there are four main obstacles to housing reconstruction; (7) the slow pace of the reconstruction is a function of social causes related to the size of the tsunami, the lack of established adjustment mechanisms for aid groups, the slow pace of the reconstruction in society overall, and the failure of market functions; (8) that in the case of large scale disasters, with the loss of life and home, as well as infrastructure, the collapse of society as an entity occurs as well.
\end{abstract}

\section{INTRODUCTION}

This paper, based on the results of research by the Sumatra Earthquake Research Team, Graduate School of Environmental Studies, Nagoya University (Graduate School of Environmental Studies, Nagoya University, 2005, 2006, 2007; Kimata et al., 2006), investigates the reconstruction process in the two-year postSumatra Earthquake period focusing on Banda Aceh and its surrounding region, Province of Nanggroe Aceh Darussalam (hereinafter, NAD), Indonesia. This team has thus far conducted four field surveys, which include interviews of local residents and relevant agencies, a questionnaire survey (described herein), and the collection of statistical data from just one month after the tsunami onward.

First is a description of the characteristics of the tremendous damage brought to Banda Aceh due to the tsunami that accompanied the Sumatra Earthquake. In concrete terms, this includes an explanation of the nature of the tsunami wave itself, which brought destruction of structures and loss of human life, resulting in the collapse of the family. In addition, in explaining the background to this human catastrophe, the lack of a conceptualization of 'a tsunami following an earthquake,' which is to say the lack of an earthquake-tsunami association, is pointed out.

Next, focusing on the reconstruction of housing, the investigation examines in detail the gaps between the reconstruction schemes presumed by the governments and aid providers, both recovery and reconstruction, and the reality, and social causes for the gaps. In this regard, four area-types of material and human damage can be identified, each with its own reconstruction characteristics to address and each offering an example of why the reconstruction objectives were not met. Finally, the investigation offers various factors of the Aceh context in explaining the slow pace of reconstruction.

\section{THE STATE OF DAMAGE}

\subsection{Topographical Conditions and the Characteristics of Damage}

The Banda Aceh Plain is an alluvial plain resulting from the deposition of sand and soil mainly from the Aceh River, flowing northward on a graben which was formed by movement of the Sumatra Fault (Fig. 1). Focusing on the downstream areas, the plain is characterized by deltaic and tidal lowland in the western part of the Drainage Canal of Aceh River, and by distinct rows of beach ridges and swales in the eastern part. The elevation of the plain is 1-3 meters above sea level in the former, except for the higher parts of natural levees along the present and abandoned river channels, while the latter is low-lying, with a small sand dune alongside beach ridges of 1-2 meters above the swale. This delta emerged mainly as a wide tidal area spreading over the 1-2 kilometers to the coast, which, based on the topographical map made in the 1940s, had given over to a widespread mangrove forest.

The older villages for the most part are located on slightly higher places as natural levees, beach ridges and sand dunes. The city of Banda Aceh was originally developed in an area with natur- 


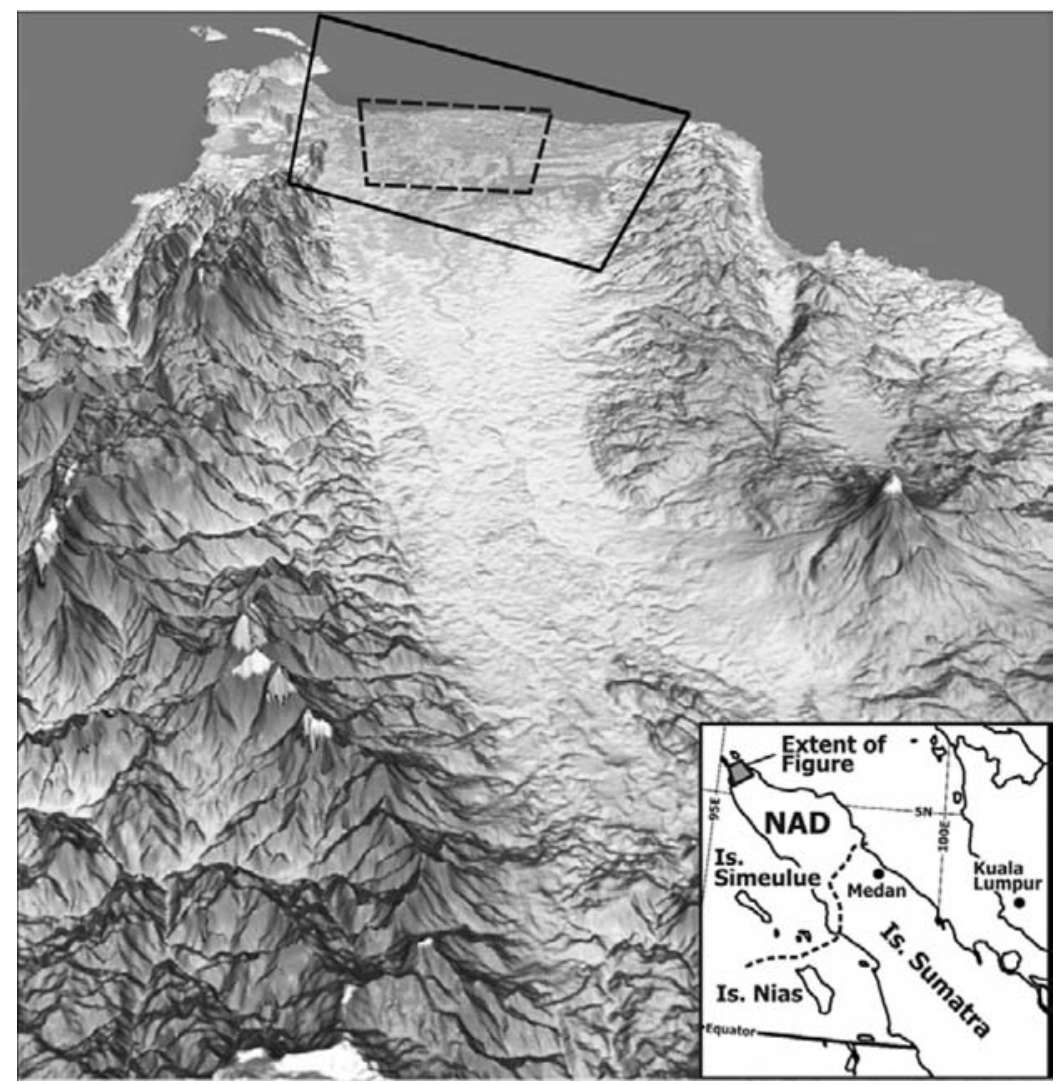

Fig. 1 Topographical Diagram of the Banda Aceh Plain

The solid and lined frames indicate the extents of Figures 2 and 3, respectively Drawn by Umitsu based on SRTM-DEM Data

al levees being bordered on the north by the tidal flats. However, as the land surrounding Banda Aceh City has continued changing, urbanization and sprawl into the flood plain and tidal flats has brought cutting of the mangrove forest and diversions in economic activities such as pond cultivation and salt farming.

Based on Umitsu's (Umitsu et al., 2007) estimation of the direction and height of the tsunami by tracing marks of the waves on the remaining structures, there is evidence of four specific characteristics of the three surges of the tsunami that began around 8:15 A.M. (see Fig. 2). The first is notable for the run-up flows that are conjectured to have caused more substantial damage than the back wash flows leaving little evidence. The second is based on the main tsunami run-up flows from the Benggala Straits, oriented from a northwest to southeast direction. A nine-meter tsunami advanced at the estuary of the Lhobi River through the Ulee Lheue area, causing inundation 2-3 kilometers upstream in the city area of Banda Aceh and leaving traces as far inland as 4-5 kilometers. The third characteristic is the ease with which the tsunami ran upstream for long distances, estimated as far as 8 kilometers, on the Aceh River and the associated drainage canal. The fourth characteristic focuses on the collision of water in the western part of the Aceh Plain that occurred with another tsunami flow reaching from the west coast of Lho'nga, through a 3-5 meter-high valley plain.

Looking at these traces in more detail, there is a slight difference that can be noted in the action of the tsunami reflecting the varied conditions of the land between the western and the eastern parts of the plain. Which is to say, in the western part of the
Drainage Canal of Aceh River, the low-lying areas of fish/shrimp ponds and lower-rise residences could not reduce the relatively direct northwest to southeast wave action, and there was little decrease in the height of the tsunami up to the very vicinity of the downtown of Banda Aceh. On the other hand, in the eastern part, there are numerous examples in which some beach ridges and remaining mangrove forests provided an obstacle to the tsunami, reducing the wave height and breaking up the direction of flow.

\subsection{The Geographical Differences in Tsunami Damage}

Therefore, in terms of the human and material damage due to the tsunami the geographical characteristics are such that a relatively larger area of damage can be noted in the western part of the plain (see Fig. 3). Overall, based on the statistics of the city government, approximately 71,000 of the registered population of 264,000 were dead or missing in Banda Aceh, with approximately 14,000 units of buildings totally destroyed and another 7,000 partially destroyed.

Assessing the damage to structures allows for a partitioning of the region into four areas. Namely, there is a coastal area in which virtually all buildings were almost completely destroyed, with partly-eroded land having disappeared (District I), an area facing inland in which many if not most destroyed houses could be seen, but where most of the structures remain (District II), an area that was inundated by water, without serious damage to buildings (District III), and an area that had no water due to the tsunami, and in which neither buildings nor humans were affected (District IV). 


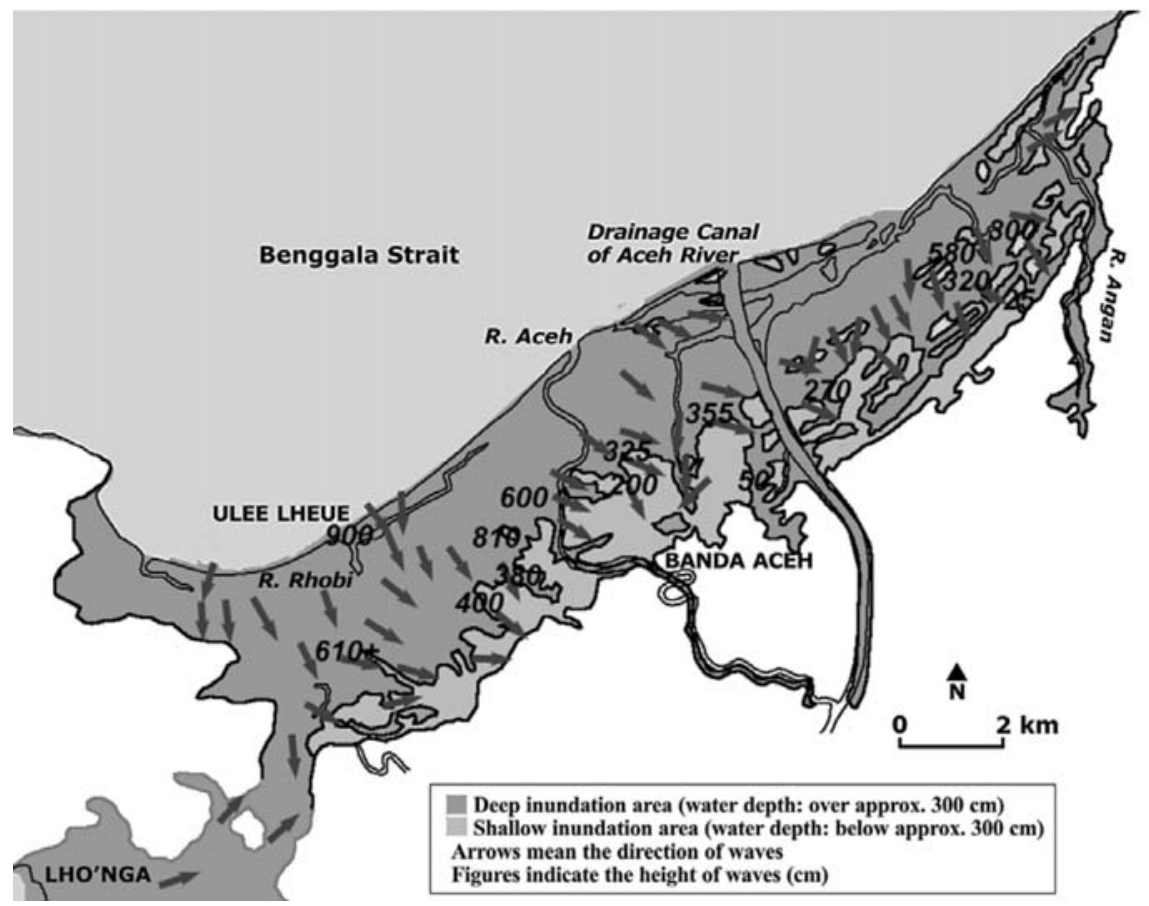

Fig. 2 Directions and Heights of the Tsunami Flow in the Banda Aceh Plain Drawn by Umitsu based on the field surveys
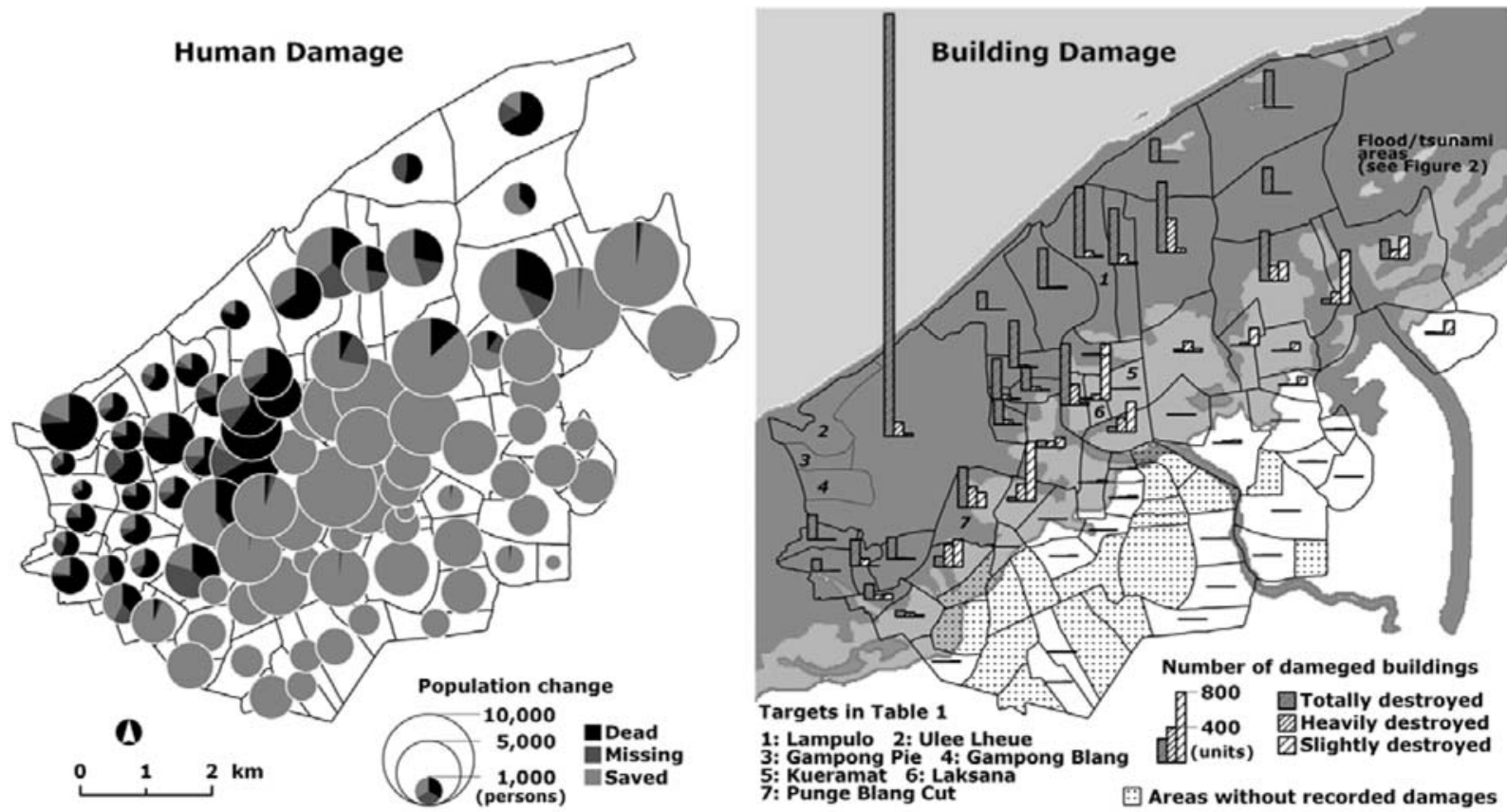

Fig. 3 Human and Material Damage due to the Tsunami Banda Aceh City Based on the statistics of the city government of Banda Aceh

Specifically, the areas of greatest damage correspond to those that were being used in the form of fishing villages on coastal and riverside areas, and low-lying areas that had undergone urbanization developing residential districts.

It is difficult if not impossible to draw clear territorial boundaries of the area-types in the nature of complicated interrelationships between tsunami flows, local-scaled geographical conditions including land uses and building structures, and degrees of damage.
As seen in Fig. 3, the extent of the heavily damaged area (District I) corresponds approximately to the deep inundation area. Meanwhile, the shallow inundation area that corresponds to the flood area represented also in several maps of the United Nations, and in which the water depth is estimated to be less than 3 meters or so, seemingly contains both Districts II and III. In the built-up areas of Banda Aceh City, for example, there is evidence that the lower the water depth was, the more easily the flow was decayed 
by densely built structures including walls, buildings and embankments as well as micro-topographies, which subsequently saved the human lives behind them. As such, Districts II and III have intricate boundaries with each other, being subject to localized geographical conditions, even though it is conceptually possible to delimit them.

The tsunami height for these areas can be surmised as approximately three meters and over for District I, approximately 1-3 meters for District II, and less than 1 meter for District III. In addition, the human cost reveals an 80-plus percent death rate for the coastal areas, countered by a gradually decreasing rate inland, with District II having a 10-20 percent death rate, and almost no deaths recorded for District III. Thus, the degrees of human damage, and material damage as well, seem to decrease progressively with distance from the coast, with a key height of the water being 3 meters. Furthermore, the damage that did occur in inland areas, especially in the vicinity of central Banda Aceh, was based on the locality of the descriptions of the characteristics provided above (for details, see Umitsu and Takahashi, 2007).

\subsection{Lack of Earthquake-Tsunami Association}

According to the United Nations, the human loss due to the Sumatra Earthquake totaled 165,000 lives in NAD Province. The magnitude of this loss can be attributed not only to the size of the tsunami, but also to the lack of a disaster subculture that is associated with tsunamis. The notion of 'earthquake-tsunami association' (Tanaka et al., 2006), which is to say that 'after an earthquake, a tsunami is likely,' is clearly not evident in local residents' action. Tsunami, rendered as 'big wave' in the Acehnese language, Ie Beuna, had been largely forgotten. For this reason, evacuation activity began only after the tsunami was witnessed by individuals or confirmed by nearby cries of 'water is coming.' Furthermore, there were no community mechanisms for disaster response. This is a critical cause of the increase of human loss. In order to improve future disaster response, in addition to the introduction of tsunami warning systems and beach embankments and buffering forests, the cultivation of a tsunami disaster subculture is important.

The processes of early evacuation lifestyle, recovery and reconstruction differed on the basis of the scale of damage. For the most part, the inundation damage sustained to structures in District III allowed for comparatively rapid reconstruction, whereas in Districts I and II, the region-wide destruction was in large part associated with the disappearance of the land itself. Due to this, the survivors in Districts I and II, while unable to remain and rebuild on the site of their housing, were obliged to move temporarily to another area of undamaged land. For this reason, most moved to evacuation shelters or IDPs (Internally Displaced Persons) sites constructed on public lands in the southeast area of the city.

Each original community constructed its own tent village. Although there were many inhabitants who evacuated to their relatives in distant locations, nevertheless, this option was unfeasible in the long term and they came together in tent villages of original community members. Most evacuees also evacuated with nothing, and therefore were totally dependent on the aid from outside organizations for a long period. In many cases, as Yamamoto (2007) points out, some community leaders temporarily established an emergency information site (Posko) to call in and arrange this aid, which functions as a reception for outside organizations, and as an information center for refugees. In this situation, contingent contact between voluntary associations and community leaders played an important role in the tent villages.

The occurrence of family collapse brought by the loss of the kinship network destroyed the capability of self-help especially in District I. Over the past thirty years, which is to say the period of the Aceh Conflict, there has been a decline in the governing function of the local government, which, combined with the death from the tsunami of the mayor of Banda Aceh City and the governor of NAD Province and the fact that government buildings also sustained tsunami damage, meant that government mechanisms did not respond sufficiently. In this, the limited governmental aid for the disaster was suspended, and the emergency provisions and medical services provided by UN organizations, overseas governments and international NGOs emerged as fulfilling a vital role.

\subsection{Damage Emerging in Families}

In order to investigate how the geographic differences in the damage affected the differences among social groups, a questionnaire survey was undertaken in December 2005, one year after the disaster. The survey targeted four areas in District I sustaining relatively heavy damage (Ulee Lheue, Gampong Pie, Gampong Blang, Lampulo) and three areas sustaining relatively light damage (Kueramat, Laksana, Punge Blang Cut), locations of which are shown in Fig. 3, using the quota-sampling method, with one individual per household sampled, followed by an interview visit, resulting in 127 responses. However, it must be noted that the estimation of the human damage is limited on the basis of such a small sample-size available for those living at the time of the survey. In some cases, all family members were casualties of the disaster or had evacuated at the time of the survey.

Looking at differences in the scale of human damage on the basis of gender and age, while there was no statistical difference found on the basis of gender, there was a statistical difference in death rates on the basis of age, with the 20-30 year old age group having the lowest rate and the over-60 year old age group along with the under-10 year old age group having the highest rates. Which is to say, death and harm is most prevalent among the youngest and the oldest. In addition, the four areas of highest damage revealed a pattern of loss in family members in which the loss of a spouse was cited by 38 percent, whereas the loss of a child, a parent or a sibling was cited by 66 percent, 95 percent and 86 percent, respectively. These results show that changes in family scale follow the severity of the disaster, as average family size in the low-damage areas changed little, from 5.7 members to 5.0, whereas in the areas of heavy damage, average family size decreased from 9.1 to 4.4. This dramatic reorganization in family structure and scale in these areas suggests the difficulty in securing the reemergence of the family unit as the fundamental unit in social life on the one hand, while on the other the difficulty in securing private aid from one's kinship network in the restoration process. In this sense, the survivors in the heavily damaged areas face a two-fold deprivation (Table 1). 
Table 1 Changes of Family Structure before and after Tsunami. Based on the Questionnaire Survey conducted in December 2005

\begin{tabular}{|c|c|c|c|c|c|}
\hline & \multirow{2}{*}{ Location } & \multicolumn{2}{|c|}{$\begin{array}{l}\text { Average family size } \\
\text { (persons) }\end{array}$} & \multicolumn{2}{|c|}{$\begin{array}{l}\text { Rate }(\%) \text { of small families } \\
\text { (family size } \leqq 2 \text { persons) }\end{array}$} \\
\hline & & Before & After & Before & After \\
\hline \multirow{6}{*}{$\begin{array}{l}\text { Heavy } \\
\text { damage }\end{array}$} & & & & & \\
\hline & Lamintio & 9.7 & 5.8 & 4.8 & 23.8 \\
\hline & Ulee Lheue & 4.5 & 2.8 & 14.3 & 64.3 \\
\hline & Gampong Pie & 5.9 & 2.0 & - & 85.7 \\
\hline & Gampong Blang & 14.4 & 3.9 & - & 35.7 \\
\hline & Sub-total & 9.1 & 4.4 & 5.4 & 40.0 \\
\hline \multirow{4}{*}{$\begin{array}{c}\text { Less } \\
\text { damage }\end{array}$} & Kueramat & 6.0 & 6.0 & 6.7 & 6.7 \\
\hline & Laksana & 4.9 & 4.3 & 30.0 & 35.0 \\
\hline & Punge Blang Cut & 6.2 & 5.1 & 9.1 & 9.1 \\
\hline & Sub-total & 5.7 & 5.0 & 15.8 & 23.0 \\
\hline \multicolumn{2}{|l|}{ Total } & 7.4 & 4.8 & 10.6 & 29.7 \\
\hline
\end{tabular}

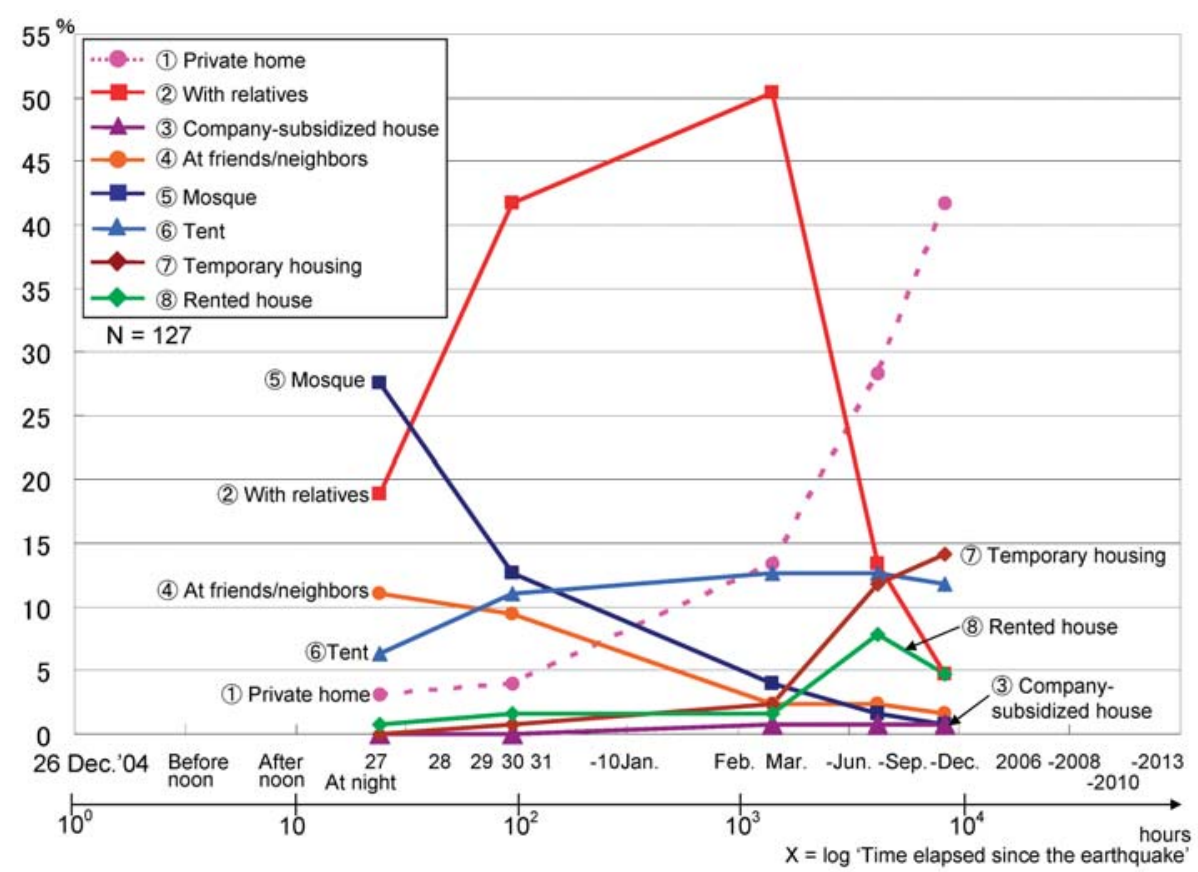

Fig. 4 Changes in the Dwelling Places in Banda Aceh Based on the Questionnaire Survey conducted in December 2005

\section{RECONSTRUCTION PROCESS}

3.1 Damage to Housing and Rebuilding as Restoration Process The paper turns now to the Banda Aceh restoration process, focusing on consideration of the housing rebuilding process.

The housing reconstruction process after a disaster in the case where the house is totally destroyed usually follows a course that begins with emergency shelters, progresses to temporary housing, and finishes with reconstructed (permanent) housing. This process progressed quite differently in the present case.

In the Sumatra Earthquake tsunami, in NAD Province and Island Nias (hereinafter, Aceh and Nias), 500,000 people lost houses, meaning that from 80,000 to 110,000 new houses needed to be reconstructed (BRR, 2005). Just a few months after the disaster, approximately 50,000 families were in temporary housing, with 67,500 families unavoidably living in tents.

\subsection{One Year after the Tsunami}

One year after the tsunami, despite the fact that it was estimated that 110,000 houses were needed (the BRR report of 2005 referred also to 120,000 houses), just 16,200 new houses were available, with an addition 13,200 houses under construction, bringing the total to 29,400 housing units in Aceh and Nias.

As mentioned in the survey results, from the start of the disaster, few respondents were able to live in their own houses that had been destroyed or inundated by the tsunami. Directly after the earthquake, those that had evacuated to mosques moved within several days to the houses of relatives. However, two months after the disaster, while some had returned to their homes, others were still in tents, emergency temporary housing or rented housing. However, looking at Fig. 4, with only 10 percent of demand for emergency temporary housing having been met according to respondents, the housing supply in this disaster response was insufficient. Although the results of this survey cannot be directly com- 
pared, one year after the 1995 Great Hanshin-Awaji Earthquake in Japan, nearly 80 percent of people had returned to their own homes, with rental housing accounting for just 9.9 percent and emergency temporary housing just 6.3 percent, indicating that the housing reconstruction in the Sumatra tsunami case was grossly late (Kimura, 2006).

\subsection{Regional Differences in Reconstruction Two Years after the Tsunami}

The scheme for earthquake reconstruction initiated after the disaster, as shown in Fig. 5, shows that progress in infrastructural provision and housing reconstruction along with lifestyle and production activity-related reconstruction should be the focus of activity for the one to two-year period after the disaster.
Looking at the response after two years, according to the BRR report (2006a), temporary housing accounts for 14,637 units, with 51,682 permanent housing units completed in Aceh and Nias. At the beginning, 110,000 housing units were estimated as necessary, thus two years after this prerequisite was established, and efforts are 58,682 units short.

In the Banda Aceh case, what is notable is the regional configuration of housing reconstruction, as shown in Fig. 6. As could be expected, in the areas that sustained large tsunami damage, there are many houses constructed, however, it is necessary to consider the overall progress. According to the BRR-RAN database, two years after the tsunami, Banda Aceh's construction plan of 11,505 housing units has been yielding 8,777 houses, a progress rate of 76.3 percent. Looking at this figure in terms of the above figures

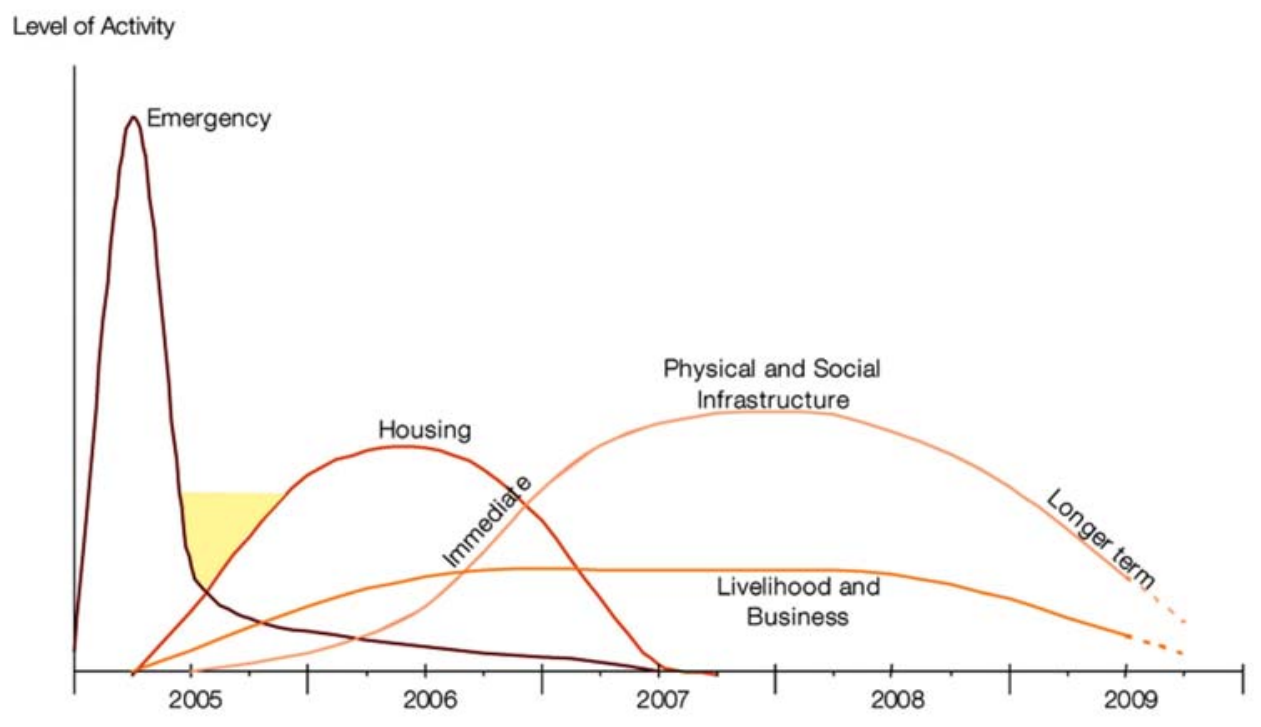

Fig. 5 Sequencing of Emergency and Recovery Effort (schematic) Cited from BRR (2005: 8)

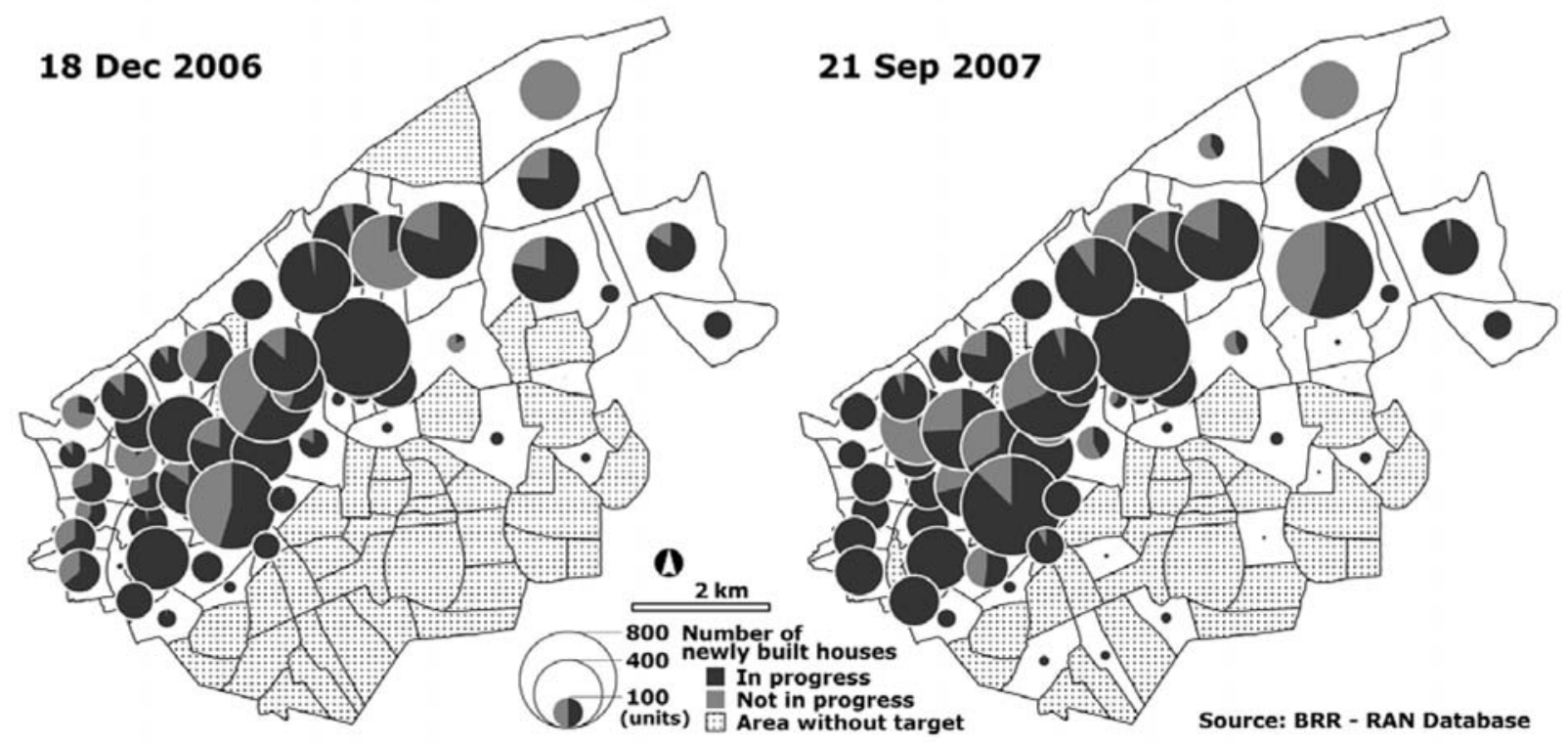

Fig. 6 Current Situation of Housing Reconstruction in Banda Aceh City Based on BRR-RAN Database 
showing approximately half the completion rate reveals an inconsistency, in which the city area of Banda Aceh has a high completion rate, whereas Aceh and Nias has an overall completion rate of just 48.3 percent. In September 2007, the housing construction advanced to a progress rate of 79.9 percent in 13,900 planned housing units within the whole city. Although many areas of heavy damage had come close to their goals, nevertheless, there were rather widened regional gaps in the progress.

A further problem is occupancy. According to our field surveys at Banda Aceh, in reality, the constructed houses appear complete from the outside. However, there are many empty houses across the severely affected areas, and in some places the flooring, windows and doors, electricity and sewers are not complete, contributing to the non-occupancy rates.

Based on classification of the tsunami damage into the four districts, housing reconstruction process can be viewed as shown in Fig. 7. Clearly, as time passes, the disaster areas represented in Districts I, II, and III reflect large differences in reconstruction processes.

\subsection{Reasons for the Lateness of Reconstruction}

What are the reasons for the slow pace of the reconstruction as outlined above? This consideration is important in thinking about the disaster reconstruction of developing countries in the future.

Four reasons can be outlined. The first reason, the magnitude of the damage, is straightforward. In the case of Banda Aceh, the approximately ten-meter tsunami occurred, in the face of which houses not built to Japanese earthquake resistant standards, such as steel-reinforced concrete and block construction, were destroyed, not to mention the loss of land mass. With this, prior to the reconstruction of housing, land boundaries, property rights and eligibility as well as inheritance and succession must be reestablished. In addition to being an area where few records were kept, in this dis- aster, the storage facilities for such records were inundated with water, meaning that these tasks were unavoidably settled based on compliance with customary law. At present, two years after the tsunami, while boundaries in 17,390 places have been established officially (BRR 2006), the loss of community leaders who know customary law means that this has taken longer than expected.

The second reason originates in the problem of the agent related to restoration. In the history of disasters, none is as large as the Sumatra Earthquake in terms of international aid. Numerous countries around the world announced aid equaling in total 2.26 billion US dollars (in reality, this came to 1.9 billion dollars), with nongovernmental aid equaling 4.2 billion dollars (Giradet, 2005: 2223). Along with this, overseas aid organizations centered on Banda Aceh numbered 535 registered groups, according to, for example, a 2005 April registration by UNOCHA office. Joining the Indonesian central government were United Nations organizations, foreign governmental aid organizations, and domestic and international NGOs of various sizes, all representing various sectors in beginning aid operations in communities. The result, for example, in Lampulo Village, a site in District I, was 15 groups (foreign governmental aid organizations: 3, UN organizations: 1, international NGOs: 10, private enterprises: 1) providing aid in supporting efforts in restoration work on housing, infrastructural preparations, health and sanitation, and education (Suhirman, 2007). In this manner, governments, United Nations, international NGOs, and other aid organizations each with different characteristics, scale and objectives, besiege one community. This results in what can be referred to as an 'aid bubble,' particularly in the first year, and brings difficulties in the regulations of these organizations. Another problem is the collapse of regional government organs and the resulting incomplete functions, meaning that the regulation mechanism does not work in communities struck by large-scale damage (Takahashi, 2007). The result is that in spite of the abun-

\section{Area Typologies by Damages to Buildings}

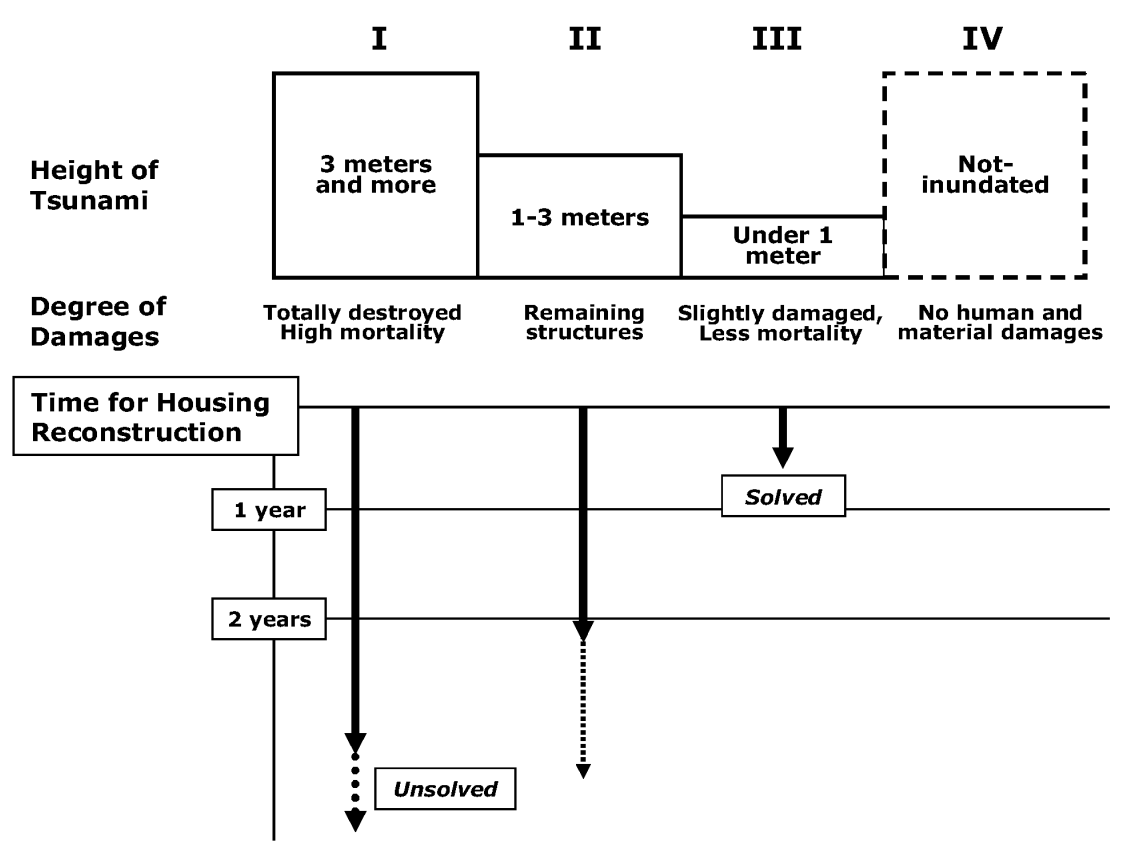

Fig. 7 Degree of Damages and Housing Reconstruction Process 
dant aid resources that exist, from the point of view of intensive and comprehensive reconstruction planning, there is confusion about the process of determining appropriate measures.

The third reason is related to the lack and wasteful duplication of reconstruction plans for the housing along with the lack of necessary resources. While reconstruction planning at the beginning was a fixed, top-down master plan paralleled by an action plan for implementation, there was a lack of core organizations and unavoidable changes in policy. This was then converted to Community-Driven Development at the community level. Furthermore, in addition to complications in the reconstruction plan, one dimension of the government related to main trunk lines and roads, harbors and water and sewage service was not requested of foreign aid or was requested too late. With this, external conditions could have little effect. Two years later, in severely damaged residential areas within the city of Banda Aceh, international NGOs continue to supply water via water pump trucks.

The fourth reason is caused by market mechanisms. Confronted with abundant finance provided by international aid organizations for housing reconstruction came a steep rise in the prices of building materials, difficulty in securing housing materials, and freight congestion of import sites, as well as difficulty in securing construction workers, and an increase in contract illegality and abandonment. With this, cases of abandonment of construction partway are not uncommon, with many cases in which the transfer is hardly completed between a constructor and an aid group. As a result, despite some progress in housing construction, many cases of non-occupancy have arisen. As is common in cases of large-scale disasters, directly after the event, price gouging and fraud are frequent, but usually government organs are empowered to monitor and the public sector is able to exert control over this market. However, in this case, one year after the disaster, prices have increased 41 percent (BRR, 2006b), meaning these controls have not been effective. Most likely, in addition to the non-functionality of government mechanisms, originally, a lack of public building standards and land use restrictions that are often seen in developing countries and avoidance of governmental intervention into the market may be a compounding factor.

The background for the four direct reasons outlined above point to a more fundamental problem. That is that along with the regional society and physical dimensions to the Sumatra tsunami were also economic, social, governmental and cultural subsistence foundations that collapsed. The tsunami disaster brought in District I a breakdown of the family along with the destruction of land and houses. With many cases of entire families perishing or losing one or two members, it was not only that the family as a unit was broken, but the wider network of relatives that the family was part of was temporarily broken up (Tabuchi, 2006). Under this circumstance the autonomous and internal economic resources of the family for restoration are lost. As for the community as well, with structural foundations such as mosques damaged and over 80 percent of the membership perished, community leaders could only reorganize the remaining members of their original village in the shelter. Several months were necessary to realize the restorative power again. Furthermore, as noted in this disaster, over 5,000 public servants of Aceh and Nias died, among them the mayor and the governor. With the first floor of government facilities flooded, many government documents were lost. The disaster collapsed government structures capable of re-integrating the potential coherence of Acehnese society, and consequently there was little public control to redistribute the economic capability of half the city area (District IV) through market functions, for example. On the other hand, GAM (Gerakan Aceh Merdeka: Free Aceh Movement), which had operated in the area of the Sumatra earthquake, and the government were able to forge a peace agreement, ending a long continuation of hostilities and bringing a new formation of government organizations. In this way, with regional government organization collapse, the central government affiliated reconstruction organization BRR (Badan Rehabilitasi dan Rekonstruksi: Agency of the Rehabilitation and Reconstruction for the Region and Community of Aceh and Nias) was established in April of 2005. It is thus not difficult to see this emergency reorganization of regional society as an ideal example of the influence of cultural structured coherence.

\section{CONCLUSION}

This research has shown: (1) the Sumatra Earthquake tsunami disaster damage in Banda Aceh can be divided into four areas; (2) the tsunami action was directed left and right by the Banda Aceh topography; (3) within which District I saw total destruction of housing, a high death rate, and the collapse of families; (4) with the high death rate due to a lack of earthquake-tsunami association; (5) that even in the core of housing reconstruction, the pace is slow; (6) there are four main obstacles to housing reconstruction; (7) the slow pace of the reconstruction is a function of social causes related to the size of the tsunami, the lack of established adjustment mechanisms for aid groups, the slow pace of the reconstruction in society overall, and the failure of market functions; (8) that in the case of large scale disasters, with the loss of life and homes, as well as infrastructure, the collapse of society as an entity occurs as well.

This research has shown that while the focus in disasters is on social damage such as deaths and loss of homes, in the future, the aspect of social collapse must be a consideration of focus as well. The reason is, in large-scale natural disasters in which a catastrophic breakup of the continuous relationship between society and the natural environment occurs, the collapse of society must bring focus on the disaster reconstruction and the process of reconstruction as a foundation in the re-emergence of a nature-society relationship.

In future, Japan's function in developing countries, especially in Asian countries in which the establishment of disaster aid, reconstruction and prevention systems will be of increasing importance. This means that interdisciplinary disaster research that comprehensively accounts for long-scale reconstruction processes in addition to natural hazard itself, along with methods of foreign aid is necessary in Japan.

\section{ACKNOWLEDGEMENT}

We acknowledge the financial support of the Graduate School of Environmental Studies and Nagoya University. We are also grateful to Mr. Suhirman (Institute of Technology Bandung), Dr. Helmi and Mr. Didik Sugiyanto (Syiah Kuala University) for their assistance in the field. 


\section{REFERENCES}

BRR, 2005. Aceh and Nias One Year After the Tsunami: The Recovery Effort and Way Forward - A Joint Report of BRR and International Partners.

BRR, 2006a. Aceh and Nias Two Years After the Tsunami: 2006 Progress Report - A Joint Report of BRR and International Partners.

BRR, 2006b. Financial Tracking Analysis of NAD Nias Reconstruction (1 September 2006), (http://www.e-aceh-nias.org/).

Giradet, E., 2005. When the World Forgets: Who Comes to Help, National Geographic Magazine, 208(6), 16-45.

Graduate School of Environmental Studies, Nagoya University, 2005. Investigation Report of 2004 Northern Sumatra Earthquake.

Graduate School of Environmental Studies, Nagoya University, 2006. Second Investigation Report of 2004 Northern Sumatra Earthquake.

Graduate School of Environmental Studies, Nagoya University, 2007. The Third Investigation Report of 2004 Northern Sumatra Earthquake.

Kimata, F., Tanaka, S., and Kimura, R., 2006. Cho-kyodai jishin ga yattekita (Super-giant Earthquake had come), Jijitsushin-sha, Tokyo (in Japanese).

Kimura, R., 2006. The Questionnaire Survey and Life Reconstruction of Victims, Graduate School of Environmental Studies, Nagoya University, Second Investigation Report of 2004 Northern Sumatra Earthquake, 137-142 (in Japanese).

Suhirman, 2007. Mapping Key Actors in Community Housing and Infrastructure Development after Earthquake and Tsunami in Banda
Aceh December 2004 - December 2006, Graduate School of Environmental Studies, Nagoya University, The Third Investigation Report of 2004 Northern Sumatra Earthquake, 64-68.

Tabuchi, R., 2006. The Questionnaire Survey and Damage to the Family, Graduate School of Environmental Studies, Nagoya University, Second Investigation Report of 2004 Northern Sumatra Earthquake, 137-142 (in Japanese).

Takahashi, M., 2007. Housing Reconstruction in Aceh and Coordination Mechanisms around Local Communities, Graduate School of Environmental Studies, Nagoya University, The Third Investigation Report of 2004 Northern Sumatra Earthquake, 58-63 (in Japanese).

Tanaka, S., Tabuchi, R., Kimura, R. and Wu, G., 2006. Tsunami Evacuation Behavior Reconsidered, Journal of Japan Society for Natural Disaster Science, 26(3), 183-195 (in Japanese with English Abstract).

Umitsu, M. and Takahashi, M., 2007. Geo-environmental Features in the Damages of the 2004 Indian Ocean Tsunami in/around Banda Aceh, Indonesia, E-journal GEO, 2(3), 142-152 (in Japanese with English Abstract).

Umitsu, M., Tanavud, C. and Patanakanog, B., 2007. Effects of Landforms on Tsunami Flow in the Plains of Banda Aceh, Indonesia and Nam Khem, Thailand, Marine Geology, 242, 141-153.

Yamamoto, H., 2007. An Interaction between Outside and Affected Societies with a Case of Post-tsunami Aceh, Senri Ethnological Reports, 73, 71-82 (in Japanese). 